AMD-20XX-XXXX

\title{
W(H)ITHER THE PEASANTRY IN THE WORK OF THE ACADEMY?
}

\section{GIBSON BURRELL}

Universities of Leicester and Manchester, UK

g.burrell@leicester.ac.uk

gibson.burrell@manchester.ac.uk

This piece is based on work funded by a Leverhulme Emeritus Fellowship 
In order to be forward looking and to surface ill-understood phenomena, we must first turn our heads to look back. We, a community of business and management scholars, should peer back in time to peoples, places, processes, procedures, practices and politics from which the vast majority of us come - the peasantry. Within almost every city dweller lives a peasant, whether we like it or not. And most of us do not like it, because across the modern world the peasantry is held in very poor regard. As besmirched dirt farmers, the peasant is seen as 'soiled' by all those who wish to embrace industrialization and preside over the necessary demise of backward feudalism (Handy 2009). The 'Economist' in its earliest editions in the 1840s specifically advocated the end of the peasantry in order to liberate Britain's economic potential which it saw as being held back by preindustrial conservativism. Thus, the modern business corporation became built upon the transmogrification of peasants into useful 'employees' within a generation or two. The thesis of 'industrialization through the eradication of the peasantry' is to be found in development theories of both the political Left and the Right and it produces a set of practices discernible almost everywhere. These include, for example, the intentional lure of the bright lights of the city and the controlled, warmish atmosphere of the factory compared to the harsh dark winters on small scale agricultural holdings. But almost everywhere, bringing peasantry to an end was done in the teeth of opposition to the ending of a way of life. Not only did the Junkers aristocratic landlords resist de-peasantrization because it brought feudalism to an end upon their vast estates, but so too did the peasant. Close ties to the land, to place, to family and to multi-generational history figured large in resistance to forced industrialization but so did the real rigors of factory life run by bell and whistle rather than the rise and fall of the sun. Most important of all these pressures towards de-peasantrization was the forcible expulsion of peasants from the soil upon which they had lived for generations. Waves of land clearances, coercive enclosure of common land and legal dispossession of those that had no piece of paper to prove their long tenure, took place in order that the cities and factories were built and peasants 'encouraged' to fill them. This is the narrative of which we $21^{\text {st }}$ century dwellers in the West have been told. We are rendered what we are because our origins upon the land are so distant as to be unknown to us.

There is only one problem with this narrative of the inexorable demise of the peasantry and that is, it hasn't happened! The numbers simply do not allow one to speak of peasantry's end. In the first issue of the 'Journal of Peasant Studies' in 1973, Eric Hobsbawn predicts the end of the peasantry in ways that speak of irresistible processes to ensure industrial capitalism progressively dominates all other forms of social and economic arrangement. Yet, 45 years later, the peasantry continues to expand in number. Of the 7 billion people upon the planet, perhaps a half remain 'peasants' where this refers to living upon the land and relying upon one's own labor and that of one's family to undertake agriculture for subsistence with very little capital and very little cash cropping. Of course, estimates vary since this category of human is least known to the state and its statistics because of its distance from the metropolitan heartland. Yet even the World Bank recognizes a minimum of 1.5 billion peasants exist today, despite all the economic forecasts which held this continuity to be impossible. At the other end of current guestimates, the Via Campinesa (Martinez-Torres et al 2010) 
estimates 3.5 billion people live a peasant lifestyle today in 2019. Of course, we are all aware of Chinese and Indian attempts this century to industrialize and the forcible (and voluntary) movements of rural populations into factories and cities entailed in these countries. But this is only a partial story. For the city often encourages declining birth rates within the urban population. In the countryside, larger families mean easier work on the land, and for this reason, birth rates amongst the peasantry remain higher than elsewhere. Numerically then, the peasantry are growing in number today despite all the socio-economic pressures of which we have spoken to eradicate them entirely.

So why should this be of any interest to contemporary readers of Business and Management journals? My answer is three fold. First, the peasantry represents a huge section of the world's population which we have not sought to understand nor address in our research in any way whatsoever. This needs to be done to have any sense of global dynamics and to the underlying processes which drive socioeconomic activity in the contemporary world. The peasantry is currently the ghost at the table of which we occasionally hear but they are by no means central to our research and thinking. Second, the peasant mentality of closeness to the land, unbreakable ties to place and hearth, of self reliance and understandings about what subsistence farming entails in great detail, may all be part of an essential, ecologically conscious set of knowledges for a globally warmed planet. Third, unless we are of aristocratic extraction, all of our families somewhere in the recent past have been peasants. In order to understand ourselves then, and where and whence we have come from, some understanding of the peasant life and beliefs and customs and ideology might come in useful in attempting to understand a $21^{\text {st }}$ world of digits and virtual reality. For this digitized world has to be 'grounded' in real food, produced by real people in real places far from our country. Peasants. Driven not by The Economist's desire for eradication of the peasantry, our knowledge needs to be based upon deep respect for these peoples' lives, livelihoods and long term survival.

\section{References}

Handy J (2009) 'Almost Idiotic Wretchedness': A Long history of Blaming Peasants, Journal of Peasant Studies 36 (2) pp 325-344

Hobsbawm E J (1973) Peasants and Politics Journal of Peasant Studies 1:1 pp 322

Martínez-Torres, María Elena ; Rosset, Peter M. (2010)

La Vía Campesina: the birth and evolution of a transnational social movement, Journal of Peasant Studies, 37(1), pp.149-175 